\title{
Peningkatan Hasil Belajar Siswa dalam Pembelajaran Globalisasi Menggunakan Pendekatan Inkuiri
}

Sri Asih

SDN Pegajahan I Kota Cirebon; karin.ifo@gmail.com

\begin{abstract}
Abstrak. Tujuan penelitian ini adalah untuk mengetahui peningkatan hasil belajar siswa dalam pembelajaran globalisasi menggunakan pendekatan inkuiri. Metode Penelitian yang digunakan dalam penelitian ini adalah metode penelitian deskriptif. Penelitian ini dilakukan pada siswa kelas IV SDN Pegajahan 1 sebanayak 39 siswa. Teknik penarikan data menggunakan teknik tes dan teknis non tes. Hasil Penelitian menunjukan bahwa hasil belajar siswa dalam pembelajaran globalisasi menggunakan pendekatan inkuiri meningkat pada setiap siklusnya, dapat dilihat pada pra siklus nilai rata - rata siswa sebesar 58,97 dengan persentase ketuntasan klasikal 41,03\%, sedangkan pada siklus I nilai rata - rata naik menjadi 60,13 dengan persentase ketuntasan $43,09 \%$ dan pada siklus II nilai rata - rata naik menjadi 85,51 dengan persentase $94,87 \%$.
\end{abstract}

Kata Kunci: Hasil Belajar, Inkuri, PKn

Abstract. The purpose of this study was to determine the increase in student learning outcomes in learning globalization using the inquiry approach. The research method used in this research is descriptive research method. This research was conducted on grade IV students of Pegajahan 1 Elementary School with 39 students. Data collection techniques using test techniques and non-test techniques. The results showed that student learning outcomes in learning globalization using the inquiry approach increased in each cycle, it can be seen in the pre-cycle average value of students of 58.97 with a classical percentage of completeness $41.03 \%$, whereas in the first cycle the average value increased to 60.13 with a percentage of completeness of $43.09 \%$ and in the second cycle the average value increased to 85.51 with a percentage of $94.87 \%$.

Keywords: Results, Study, Inquiri, PKn

\section{Pendahuluan}

Mata pelajaran PKn merupakan mata pelajaran yang memfokuskan pada pembentukan warga Negara yang memahami dan mampu melaksanakan hak-hak dan kewajiban untuk menjadi warga Negara yang cerdas, terampil, dan berkarakter yang diamanatkan oleh pancasila dan UUD 1945 (BSNP, 2006).

Caruban: Jurnal Ilmiah Pendidikan Dasar 3(1), 1-14, Januari 2020

DOI: http://dx.doi.org/10.33603/.v3i1.2897, p-ISSN 2615-1391, e-ISSN 2620-3219

CProdi PGSD Universitas Swadaya Gunung Jati 
Tujuan pembelajaran PKn dalam BSNP (2006)adalah untuk memberikan kompetensi sebagai berikut : berfikir kritis, rasional, dan kreatif dalam menanggapi isu kewarganegaraan, berprestasi secara cerdas dan tanggung jawab serta bertindak secara sadar dalam kegiatan bermasyarakat, berbangsa, dan bernegara, berkembang secara positif dan demokratis untuk membentuk diri berdasarkan karakter-karakter masyarakat di Indonesia agar dapat hidup bersama dengan bangsa-bangsa lain, berinteraksi dengan bangsabangsa lain dalam percaturan dunia secara langsung dengan memanfaatkan teknologi informasi dan komunikasi.

Mengutip salah satu tujuan pendidikan di atas yaitu memberikan keterampilan dasar bagi siswa sekolah dasar, maka dalam proses pembelajaran hal-hal yang berkaitan dengan penanaman konsep suatu pembelajaran harus benar-benar di pahami oleh siswa. Dalam proses pembelajaran sangat ditekankan bagaimana aktivitas seorang guru dalam menyampaikan pelajaran sehingga siswa mampu memahami secra tepat dan memperoleh hasil pembelajaran yang maksimal.

Berdasarkan observasi yang dilakukan oleh peneliti didapatkan bahwa masih ada hambatan dalam pembelajaran PKn kelas IV di SDN Pegajahan I, hal ini yang berkaitan dengan ketepatan penggunaan model atau pendekatan pembelajaran. Dalam pembelajaran PKn guru belum menerapkan pembelajaran yang inovatif sehingga aktivitas pembelajaran lebih didominasi guru, serta kurang memanfaatan media yang menarik bagi siswa. Guru hanya mengembangkan aktualisasi konsep tanpa diimbangi pengalaman konkret dan eksperimen aktif oleh siswanya dalam memperoleh pengetahuan.

Akibat dari proses pembelajaran yang demikian itu siswa belum diaktifkan dalam pembelajaran untuk memecahkan masalah pelajaran yang dipelajari, siswa menerima sumber belajar hanya dari guru dan buku tetapi belum mengembangkan keterampilan proses. Sehingga aktivitas siswapun belum maksimal. Hal demikian ini, membuat kualitas pembelajaran PKn kurang maksimal juga, ditunjukkan dengan hasil belajar yang rendah. Hal tersebut didukung data ulangan harian siswa pada pelajaran pendidikan kewarganegaraan siswa kelas IV SDN Pegajahan I, didefinisikan masih

Caruban: Jurnal Ilmiah Pendidikan Dasar 3(1), 1-14, Januari 2020

DOI: http://dx.doi.org/10.33603/.v3i1.2897, p-ISSN 2615-1391, e-ISSN 2620-3219

CProdi PGSD Universitas Swadaya Gunung Jati 
banyak siswa belum tuntas, ini ditunjukkan dari 39 siswa anak kelas IV hanya 16 siswa yang mendapat di atas KKM 65 atau tuntas, sedangkan 23 siswa nilainya dibawah KKM 65.

Untuk mengatasi permasalahan tersebut di atas perlu penerapan pendekatan/ model pembelajaran yang inovatif diharapkan dapat meningkatkan kualitas pembelajaran yang meliputi keterampilan guru, aktivitas siswa, dan hasil belajar siswa dalam pembelajaran PKn. Berdasarkan kolaborasi tim peneliti dengan guru kelas IV menetapkan penggunaan pendekatan inkuiri dengan media video untuk meningkatkan keaktifan siswa dalam pembelajaran. Pembelajaran PKn sebaiknya dilaksanakan secara inkuiri ilmiah untuk menumbuhkan kemampuan berpikir, bekerja dan bersikap ilmiah serta mengkomunikasikannya sebagai aspek penting kecakapan hidup. Oleh karena itu, pembelajaran PKn di SD/MI menekankan pada pemberian pengalaman belajar secara langsung melalui penggunaan pengembangan keterampilan proses dan sikap ilmiah.

Menurut Sudjana (2008)pendekatan inkuiri merupakan pendekatan mengajar yang berusaha meletakkan dasar dan mengembangkan cara berpikir ilmiah. Pendekatan ini menempatkan siswa lebih banyak belajar sendiri, mengembangkan ke kreatifan dalam memecahkan masalah. Sedangkan bahan pembelajaran video merupakan bahan pembelajaran tampak dengar (audio visual) yang dapat digunakan untuk menyampaikan pesan-pesan/materi pelajaran. Bahan pembelajaran video ini akan menjadi lebih menarik perhatian siswa karena mampu menyajikan objek-objek nyata yang lokasinya jauh, berbahaya, dan mungkin belum pernah dilihatnya (Djauhar, 2008)

Guru sebaiknya menerapkan pendekatan inkuiri karena pendekatan inkuiri itu: memungkinkan untuk mengembangkan cara belajar siswa aktif, pengetahuan yang ditemukan sendiri melalui pendekatan inkuiri akan betulbetul dikuasai, siswa dapat menguasai salah satu metode ilmiah yang sangat berguna dalam kehidupannya, siswa dibiasakan berpikir analitis dan mencoba memecahkan masalah yang akan ditransfer dalam kehidupan masyarakat (Abimanyu, 2008). Menurut Wibawa \& Mukti (2011)media video dan film dapat digunakan untuk menyajikan bagian-bagian dari suatu proses dan prosedur secara utuh sehingga memudahkan siswa dalam Caruban: Jurnal Ilmiah Pendidikan Dasar 3(1), 1-14, Januari 2020 DOI: http://dx.doi.org/10.33603/.v3i1.2897, p-ISSN 2615-1391, e-ISSN 2620-3219 CProdi PGSD Universitas Swadaya Gunung Jati 
mengamati, dan menirukan, langkah-langkah suatu prosedur yang harus dipelajari.

Berdasarkan ulasan latar belakang di atas maka peneliti akan mengkaji melalui penelitian tindakan kelas dengan judul "Peningkatan Hasil Belajar Siswa Dalam Pembelajaran Globalisasi Menggunakan Pendekatan Inkuiri Pada Kelas IV SDN Pegajahan I Kota Cirebon".

\section{Metode}

Metode penelitian yang digunakan dalam penelitian ini adalah metode penelitian deskriptif. Penelitian ini dilakukan pada siswa kelas IV SDN Pegajahan I sebanyak 39 siswa yang terdiri dari 19 siswa laki-laki dan 20 siswa perempuan.

Pelaksanaan penelitian ini mengikuti tahap-tahap penelitian tindakan kelas yang pelaksanaan tindakannya terdiri atas beberapa siklus. Setiap siklus terdiri atas 4 tahap dalam sebuah daur ulang yaitu perencanaan tindakan (planning), penerapan tindakan (action), mengobservasi, dan mengevaluasi proses dan hasil tindakan (observation and evaluation) dan melakukan refleksi (reflecting), dan seterusnya sampai perbaikan atau peningkatan yang diharapkan tercapai (kriteria keberhasilan)

Tes adalah himpunan pertanyaan yang harus dijawab, pertanyaanpertanyaan yang harus dipilih/ditanggapi, atau tugas-tugas yang harus dilakukan oleh peserta tes dengan tujuan untuk mengukur suatu aspek tertentu dari peserta tes (Poerwanti, 2008). Dalam penelitian ini teknik tes digunakan untuk mengukur hasil belajar siswa dalam memahami pelajaran PKn pada materi globalisasi pada siswa kelas IV SDN Pegajahan I Kota Cirebon.

Observasi adalah alat pengumpulan data yang dilakukan dengan cara mengamati dan mencatat secara sistematik gejala-gejala yang diselidiki (Narbuko \& Ahmadi, 2007). Observasi dalam penelitian ini digunakan untuk mengamati keterampilan guru dan siswa dalam pembelajaran globalisasi menggunakan pendekatan inkuiri.

Caruban: Jurnal Ilmiah Pendidikan Dasar 3(1), 1-14, Januari 2020

DOI: http://dx.doi.org/10.33603/.v3i1.2897, p-ISSN 2615-1391, e-ISSN 2620-3219

CProdi PGSD Universitas Swadaya Gunung Jati 
Metode dokumentasi yaitu mencari data mengenai hal-hal atau variabel yang berupa catatan lapangan, transkrip, buku, surat kabar, majalah, prasasti, notulen rapat, agenda dan sebagainya (Arikunto, 2013). Dokumen yang digunakan dalam penelitian ini berupa daftar hadir siswa, lembar kerja siswa, dan catatan lapangan. Untuk memberikan gambaran secara konkrit mengenai kegiatan kelompok siswa dan menggambarkan suasana kelas ketika kegiatan belajar berlangsung digunakan dokumentasi foto dengan bantuan alat kamera.

\section{Hasil dan Pembahasan}

\section{Deskripsi Data Pelaksanaan Tindakan Kelas Siklus I}

Penelitian tindakan kelas pada mata pelajaran PKn materi globalisasi menggunakan pendekatan inkuiri di kelas IV SDN Pegajahan I Kota Cirebon dilakukan melalui dua siklus. Pada siklus I diperoleh hasil belajar sebagai berikut.

Tabel 1. Hasil Belajar Siswa pada Siklus I

\begin{tabular}{clcl}
\hline No & Nama Siswa & Nilai & Keterangan \\
\hline 1 & Ahmad Muhsin & 65 & Tuntas \\
2 & Aida Anggraeni & 50 & Tidak Tuntas \\
3 & Alya Khikar Sukma Putri & 65 & Tuntas \\
4 & Asmiranda Ramadani & 55 & Tidak Tuntas \\
5 & Cantika Dwi Rahma Erianto & 60 & Tidak Tuntas \\
6 & Danar Bahtiar & 55 & Tidak Tuntas \\
7 & David Nurul Azmi & 70 & Tuntas \\
8 & Dekki Agung Hermawan & 50 & Tidak Tuntas \\
9 & Dimas Aditia & 65 & Tuntas \\
10 & Fauzan Alfian Firmansyah & 50 & Tidak Tuntas \\
11 & Hanin Nur Haly & 70 & Tuntas \\
12 & Hanyfa Maulidha & 50 & Tidak Tuntas \\
13 & Hasbi Maulana & 65 & Tuntas \\
14 & Helmi Aditya & 50 & Tidak Tuntas \\
15 & Ihwan Nugraha & 65 & Tuntas \\
16 & Indah Indriyana Basman & 50 & Tidak Tuntas \\
17 & Khaerul Yahya & 55 & Tidak Tuntas \\
18 & Linda Sevira & 55 & Tidak Tuntas \\
19 & Michele Imanuel Teja & 50 & Tidak Tuntas \\
20 & Mischa Daud Ardian & 70 & Tuntas \\
\hline
\end{tabular}

Caruban: Jurnal Ilmiah Pendidikan Dasar 3(1), 1-14, Januari 2020

DOI: http://dx.doi.org/10.33603/.v3i1.2897, p-ISSN 2615-1391, e-ISSN 2620-3219

CProdi PGSD Universitas Swadaya Gunung Jati 


\begin{tabular}{llcl}
\hline No & Nama Siswa & Nilai & Keterangan \\
\hline 21 & Mochamad Alvian. A & 60 & Tidak Tuntas \\
22 & Mohamad Yusuf Saputra & 50 & Tidak Tuntas \\
23 & Muh. Irfan Maulana & 70 & Tuntas \\
24 & Mutiara Fadilah & 75 & Tuntas \\
25 & Nabila Saleeman & 50 & Tidak Tuntas \\
26 & Nisa Nurhabibah & 75 & Tuntas \\
27 & Nur Aliyah & 60 & Tidak Tuntas \\
28 & Raenaldi & 50 & Tidak Tuntas \\
29 & Rafli Aditia & 50 & Tidak Tuntas \\
30 & Reivan Dwi Febriana & 70 & Tuntas \\
31 & Rifai Maulana & 65 & Tuntas \\
32 & Sarah Rahayu & 55 & Tidak Tuntas \\
33 & Sherly Amaliah Putri & 70 & Tuntas \\
34 & Siti Rahayu & 80 & Tuntas \\
35 & Syafa Aulya Putri & 55 & Tidak Tuntas \\
36 & Titania & 65 & Tuntas \\
37 & Tristan Ahmad Dafa & 60 & Tidak Tuntas \\
38 & Vanesa Lintang Syabani & 50 & Tidak Tuntas \\
39 & Widiya Arum Sari & 70 & Tuntas \\
& Jumlah & $\mathbf{2 3 4 5}$ & \\
& $\quad$ Rata - Rata & $\mathbf{6 0 , 1 3}$ & Tidak tuntas \\
& Nilai Tertinggi & $\mathbf{5 0}$ & \\
\hline
\end{tabular}

Tabel 2. Persentase Hasil Belajar Siswa pada Siklus I

\begin{tabular}{ccccc}
\hline No & Nilai & Jumlah Siswa & Jumlah Nilai & Persentase \\
\hline 1. & 100 & 0 & 0 & \\
2. & 95 & 0 & 0 & \\
3. & 90 & 0 & 0 & \\
4. & 85 & 0 & 0 & \\
5. & 80 & 1 & 80 & \\
6. & 75 & 2 & 150 & \\
7. & 70 & 7 & 490 & \\
8. & 65 & 7 & 455 & \\
9. & 60 & 4 & 240 & \\
10. & 55 & 6 & 330 & \\
11. & 50 & 12 & $\mathbf{2 3 4 5}$ & \\
\hline
\end{tabular}

Caruban: Jurnal Ilmiah Pendidikan Dasar 3(1), 1-14, Januari 2020

DOI: http://dx.doi.org/10.33603/.v3i1.2897, p-ISSN 2615-1391, e-ISSN 2620-3219

CProdi PGSD Universitas Swadaya Gunung Jati 
Berdasarkan tabel di atas dapat dijelaskan bahwa nilai tes formatif yang diperoleh berbeda - beda dari nilai 50 hingga nilai 80. Siswa yang mendapatkan nilai $\leq 65$ ada 22 siswa dan 17 siswa mendapatkan nilai $\geq$ 65 dengan rata - rata 60,13. Pada hasil ulangan harian (pras siklus) kelas IV SDN Pegajahan I materi globalisasi tahun ajaran 2016 / 2017 rata-rata hasil belajar siswa hanya 58,97 sedangkan pada siklus I hasil belajar siswa 60,13 sehingga terjadi kenaikan. Kenaikan hasil belajar siswa ini dapat digambarkan pada grafik halaman berikut ini.

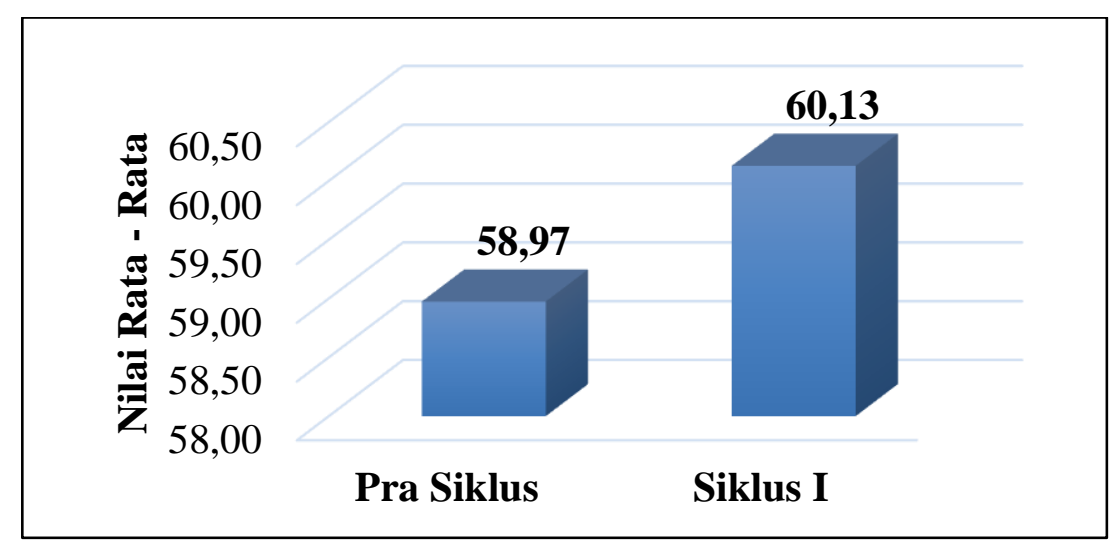

Gambar 1. Grafik Kenaikan Hasil Belajar Siswa pada Siklus I

Grafik di atas menunjukkan adanya peningkatan hasil belajar siswa dari sebelum dilakukan penerapan dengan pendektan inkuiri yaitu rata - rata 58,97 meningkat menjadi 60,13 setelah guru menerapkan pendekatan inkuiri pada materi globalisasi kelas IV. Pada siklus I pun siswa sudah mencapai ketuntasan belajar sebesar 43,09\%. Ketuntasan belajar siswa dapat digambarkan pada diagram halaman berikut.

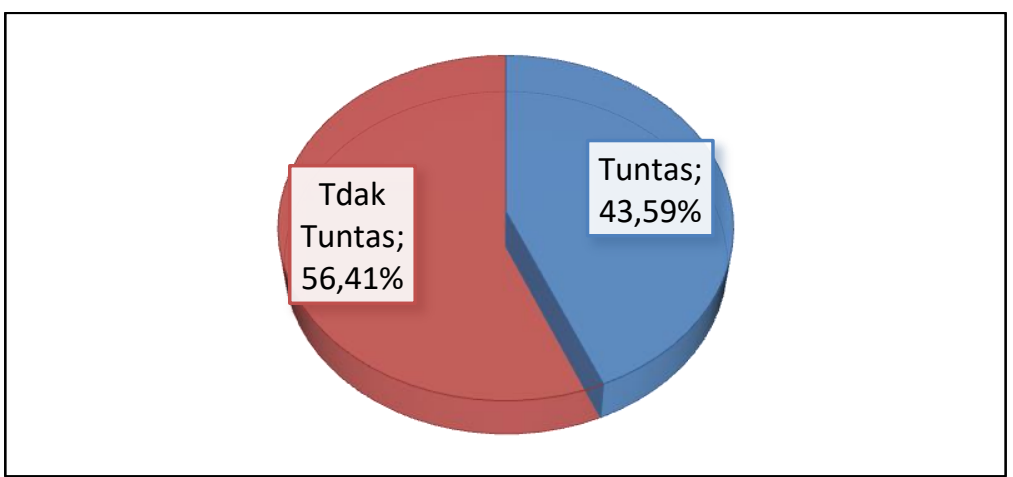

Gambar 2. Grafik Persentase Ketuntasan Belajar Siswa Siklus I

Caruban: Jurnal Ilmiah Pendidikan Dasar 3(1), 1-14, Januari 2020

DOI: http://dx.doi.org/10.33603/.v3i1.2897, p-ISSN 2615-1391, e-ISSN 2620-3219

CProdi PGSD Universitas Swadaya Gunung Jati 


\section{Deskripsi Data Pelaksanaan Tindakan Kelas Siklus II}

Hasil belajar siswa pada siklus II dapat dilihat pada tabel di bawah ini.

Tabel 3. Hasil Belajar Siswa pada Siklus II

\begin{tabular}{|c|c|c|c|}
\hline No & Nama Siswa & Nilai & Keterangan \\
\hline 1 & Ahmad Muhsin & 90 & Tuntas \\
\hline 2 & Aida Anggraeni & 80 & Tuntas \\
\hline 3 & Alya Khikar Sukma Putri & 80 & Tuntas \\
\hline 4 & Asmiranda Ramadani & 100 & Tuntas \\
\hline 5 & Cantika Dwi Rahma Erianto & 90 & Tuntas \\
\hline 6 & Danar Bahtiar & 75 & Tuntas \\
\hline 7 & David Nurul Azmi & 80 & Tuntas \\
\hline 8 & Dekki Agung Hermawan & 70 & Tuntas \\
\hline 9 & Dimas Aditia & 100 & Tuntas \\
\hline 10 & Fauzan Alfian Firmansyah & 75 & Tuntas \\
\hline 11 & Hanin Nur Haly & 90 & Tuntas \\
\hline 12 & Hanyfa Maulidha & 85 & Tuntas \\
\hline 13 & Hasbi Maulana & 80 & Tuntas \\
\hline 14 & Helmi Aditya & 75 & Tuntas \\
\hline 15 & Ihwan Nugraha & 80 & Tuntas \\
\hline 16 & Indah Indriyana Basman & 75 & Tuntas \\
\hline 17 & Khaerul Yahya & 95 & Tuntas \\
\hline 18 & Linda Sevira & 85 & Tuntas \\
\hline 19 & Michele Imanuel Teja & 70 & Tuntas \\
\hline 20 & Mischa Daud Ardian & 95 & Tuntas \\
\hline 21 & Mochamad Alvian. A & 75 & Tuntas \\
\hline 22 & Mohamad Yusuf Saputra & 60 & Tidak Tuntas \\
\hline 23 & Muh. Irfan Maulana & 90 & Tuntas \\
\hline 24 & Mutiara Fadilah & 100 & Tuntas \\
\hline 25 & Nabila Saleeman & 60 & Tidak Tuntas \\
\hline 26 & Nisa Nurhabibah & 100 & Tuntas \\
\hline 27 & Nur Aliyah & 90 & Tuntas \\
\hline 28 & Raenaldi & 70 & Tuntas \\
\hline 29 & Rafli Aditia & 90 & Tuntas \\
\hline
\end{tabular}

Caruban: Jurnal Ilmiah Pendidikan Dasar 3(1), 1-14, Januari 2020

DOI: http://dx.doi.org/10.33603/.v3i1.2897, p-ISSN 2615-1391, e-ISSN 2620-3219

CProdi PGSD Universitas Swadaya Gunung Jati 


\begin{tabular}{llll}
\hline No & Nama Siswa & Nilai & Keterangan \\
\hline 30 & Reivan Dwi Febriana & 100 & Tuntas \\
31 & Rifai Maulana & 80 & Tuntas \\
32 & Sarah Rahayu & 100 & Tuntas \\
33 & Sherly Amaliah Putri & 100 & Tuntas \\
34 & Siti Rahayu & 100 & Tuntas \\
35 & Syafa Aulya Putri & 80 & Tuntas \\
36 & Titania & 95 & Tuntas \\
37 & Tristan Ahmad Dafa & 95 & Tuntas \\
38 & Vanesa Lintang Syabani & 80 & Tuntas \\
39 & Widiya Arum Sari & 100 & Tuntas \\
Jumlah & & $\mathbf{3 3 3 5}$ & \\
Rata - Rata & $\mathbf{8 5 , 5 1}$ & Tuntas \\
Nilai Tertinggi & $\mathbf{1 0 0}$ & \\
Nilai Terendah & $\mathbf{6 0}$ & \\
\hline
\end{tabular}

Tabel 4. Persentase Hasil Belajar Siswa pada Siklus II

\begin{tabular}{lllll}
\hline No & Nilai & Jumlah Siswa & Jumlah Nilai & Persentase \\
\hline 1. & 100 & 9 & 900 & \\
2. & 95 & 4 & 380 & \\
3. & 90 & 6 & 540 & \\
4. & 85 & 2 & 170 & \\
5. & 80 & 8 & 640 & \\
6. & 75 & 5 & 375,51 \\
7. & 70 & 3 & 210 & \\
8. & 65 & 0 & 0 & \\
9. & 60 & 2 & 120 & \\
10. & 55 & 0 & 0 & \\
11. & 50 & 0 & 0 & \\
Jumlah & 39 & 3335 & \\
\hline
\end{tabular}

Berdasarkan tabel di atas dapat dijelaskan bahwa nilai tes formatif terjadi perbedaan antara siklus I dan siklus II. Siswa yang mendapatkan nilai $\geq 65$ pada siklus II yaitu 37 siswa. Hal ini menunjukkan bahwa pembelajaran globalisasi menggunakan 
pendekatan inkuiri dapat meningkatkan hasil belajar siswa. Pada siklus I nilai rata - rata hasil belajar siswa 60,13 sedangkan pada siklus II nilai rata rata hasil belajar siswa yaitu 85,51 . Kenaikan hasil belajar siswa ini dapat digambarkan pada grafik halaman berikut.

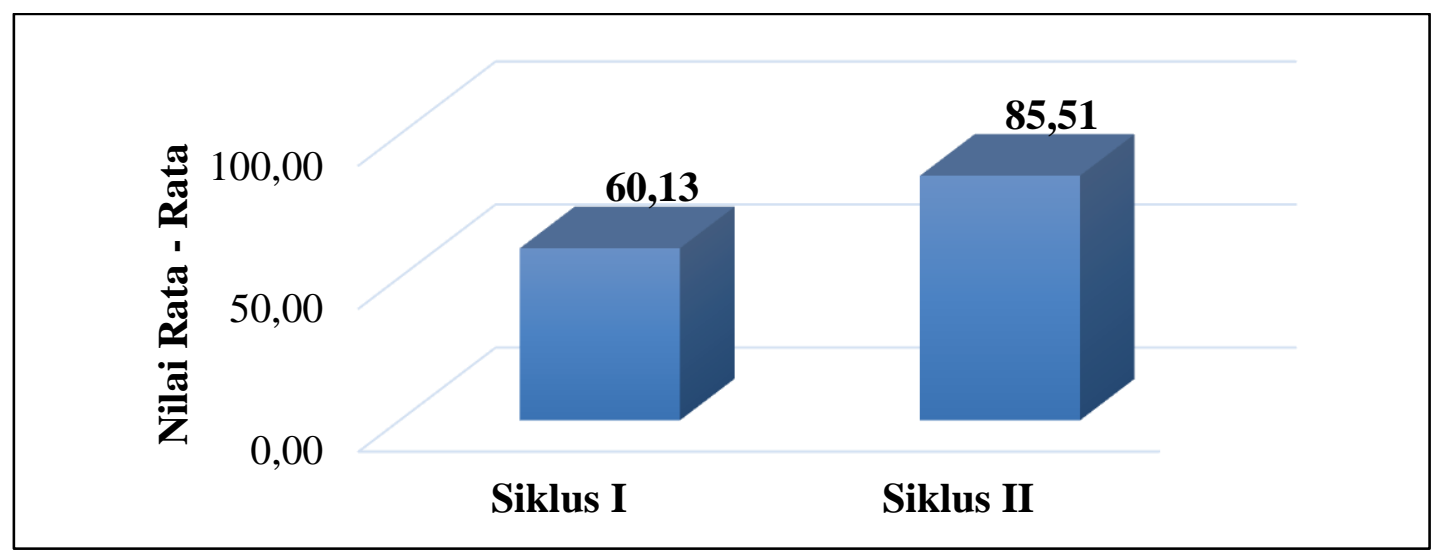

Gambar 3. Grafik Kenaikan Hasil Belajar Siswa pada Siklus II

Berdasarkan grafik di atas dapat dijelaskan bahwa pembelajaran globalisasi menggunakan pendekatan inkuiri dapat meningkatkan hasil belajar siswa pada siklus I dan siklus II. Pada siklus I rata-rata nilai yang diperoleh siswa adalah 60,13 sedangkan pada siklus II rata-rata nilai yang diperoleh siswa adalah 85,51. Maka terjadi peningkatan sebesar 25,38 pada hasil belajar siswa. Pada siklus II pun ketuntasan belajar siswa meningkat. Ketuntasan belajar siswa pada siklus II mencapai 94,87\%. Hal ini dapat dikatakan telah mencapai ketuntasan yaitu sudah memenuhi indikator keberhasilan yang telah ditentukan sekurang - kurangnya 80\% siswa yang mendapat nilai $\geq 65$. Adapun ketuntasan belajar siswa pada siklus II dapat digambarkan pada diagram di bawah ini.

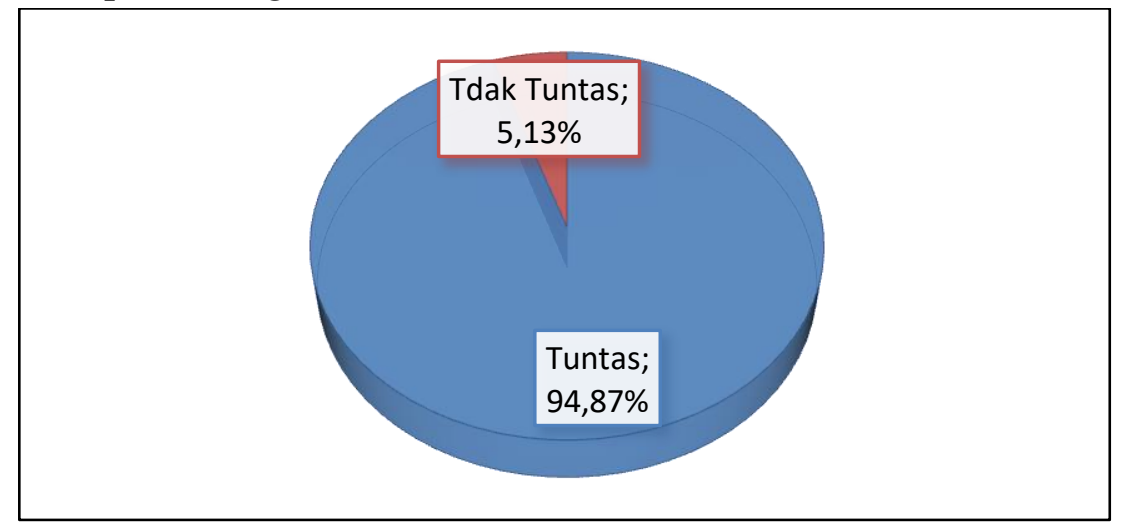

Gambar 4. Grafik Persentase Ketuntasan Belajar Siswa Siklus II

Caruban: Jurnal Ilmiah Pendidikan Dasar 3(1), 1-14, Januari 2020

DOI: http://dx.doi.org/10.33603/.v3i1.2897, p-ISSN 2615-1391, e-ISSN 2620-3219

CProdi PGSD Universitas Swadaya Gunung Jati 
Berdasarkan hasil analisis data, penulis dalam menerapkan pendekatan inkuiri di kelas IV pada mata pelajaran PKn materi globalisasi sudah berhasil. Hal ini ditunjukkan dengan adanya peningkatan hasil belajar siswa. Pada semester genap tahun pelajaran 2016/2017 keberhasilan siswa dalam mencapai KKM hanya 41,03\% dengan rata-rata nilai 58,97. Hasil yang diperoleh ini tentu belum sesuai dengan KKM dan rata-rata kelas. Setelah dilakukan pembelajaran globalisasi menggunakan pendekatan inkuiri pada siklus I dan siklus II menjadi meningkat yaitu keberhasilan siswa pada siklus I adalah 43,09\% dengan rata-rata nilai 60,13 dan pada siklus II keberhasilan siswa mencapai nilai di atas KKM meningkat menjadi $94,87 \%$ dengan rata-rata nilai 85,51 .

Hasil yang telah didapat sudah sesuai dengan indikator keberhasilan hasil belajar siswa, yaitu telah mencapai rata-rata kelas sekurang - kurangnya 65 dan persentase tuntas klasikal sekurangkurangnya 65\% siswa yang mendapatkan skor $\geq 65$ (KKM Sekolah). Hal ini dapat dikatakan bahwa pada kenyataannya pendekatan inkuiri dapat meningkatkan pemahaman siswa terhadap materi yang dipelajari sehingga berpengaruh pada peningkatan hasil belajar siswa yang diperoleh melalui tes formatif.

Pada aktivitas siswa, selama pembelajaran globalisasi menggunakan pendekatan inkuiri seluruh siswa kelas IV SDN Pegajahan I Kota Cirebon mengikuti dengan baik. Kehadiran siswa sebesar 100\% dalam pembelajaran globalisasi menggunakan pendekatan inkuiri ini menunjukkan ketertarikan siswa pada pembelajaran ini dan telah sesuai dengan indikator keberhasilan aktivitas siswa yaitu ketidak hadiran siswa maksimal 10\%, tetapi pada kenyataannya $100 \%$ siswa hadir dalam pembelajaran globalisasi menggunaakan pendekatan inkuiri.

Penerapan pembelajaran globalisasi menggunakan pendekatan inkuiri juga dapat meningkatkan keberanian siswa dalam bertanya atau menjawab pertanyaan. Dalam indikator keberhasilan, keberanian siswa dalam mengajukan atau menjawab pertanyaan ditentukan lebih dari 50\% dan hasil yang didapat pada siklus I adalah $43,09 \%$ sedangkan pada siklus II adalah 94,87\%. Hasil ini menunjukkan bahwa pembelajaran globalisasi Caruban: Jurnal Ilmiah Pendidikan Dasar 3(1), 1-14, Januari 2020 DOI: http://dx.doi.org/10.33603/.v3i1.2897, p-ISSN 2615-1391, e-ISSN 2620-3219 CProdi PGSD Universitas Swadaya Gunung Jati 
menggunakan pendekatan inkuiri dapat meningkatkan aktivitas keberanian bertanya atau menjawab pertanyaan. Peningkatan hasil aktivitas siswa terjadi juga pada keterlibatan siswa dalam pembelajaran globalisasi menggunakan pendekatan inkuiri. Keterlibatan siswa dalam pembelajaran globalisasi menggunakan pendekatan inkuiri meningkat dari siklus I yaitu 43,09\% menjadi 94,87\% pada siklus II. Maka dapat dikatakan bahwa keterlibatan siswa dalam pembelajaran globalisasi menggunakan pendekatan inkuiri sudah mencapai indikator keberhasilan yaitu lebih dari $80 \%$.

Pembelajaran globalisasi menggunakan pendekatan inkuiri yang diterapkan guru di kelas ternyata bermanfaat bagi siswa. Pembelajaran ini selain mampu memberikan pengetahuan kepada siswa juga mampu mengaktifkan siswa di kelasnya baik dalam kegiatan diskusi, bertanya, mengeluarkan pendapat, maupun dalam berinteraksi dengan guru dan siswa lain. Dengan ini siswa dapat belajar sambil bermain dan bersosialisasi. Hal ini tidak lepas dari peran serta guru dalam pembelajaran globalisasi menggunakan pendekatan inkuiri. Hasil yang diperoleh guru dalam menerapkan pendekatan inkuiri pada siklus I yaitu 43,09\% sedangkan pada siklus II meningkat menjadi 94,87\%. Hal ini menunjukkan bahwa kinerja guru dalam menerapkan pendekatan inkuiri sudah baik.

Pada pembelajaran globalisasi menggunakan pendekatan inkuiri, guru memberikan kesempatan kepada siswa untuk berinteraksi dalam proses belajar mengajar sehingga peran guru di kelas bukan lagi sebagai sumber belajar satu - satunya, tetapi lebih bersifat sebagai fasilitator dan motivator bagi siswa. Hal inilah yang memicu keaktifan siswa dalam mencari pengetahuannya sendiri sehingga pengetahuan yang diperoleh siswa dengan sendiri akan melekat lebih lama dalam pikiran siswa dan meningkatkan hasil belajar siswa. Maka dapat dikatakan bahwa pendekatan inkuiri mampu menjadikan pembelajaran yang bermakna bagi siswa.

\section{Simpulan dan Rekomendasi}

Berdasarkan hasil penelitian ditarik kesimpulan bahwa keterampilan guru dalam kegiatan pembelajaran PKn mengalami peningkatan pada setiap

Caruban: Jurnal Ilmiah Pendidikan Dasar 3(1), 1-14, Januari 2020

DOI: http://dx.doi.org/10.33603/.v3i1.2897, p-ISSN 2615-1391, e-ISSN 2620-3219

CProdi PGSD Universitas Swadaya Gunung Jati 
siklus. Hal ini dibuktikan dengan hasil pada pra siklus diperoleh skor 29 dengan kategori baik, pada siklus II diperoleh skor 33 dengan kategori sangat baik dan pada siklus III meningkat dengan perolehan skor 36 dengan kategori sangat baik. Aktivitas siswa dalam kegiatan pembelajaran PKn juga mengalami peningkatan pada setiap siklus. Hal ini dibuktikan dengan hasil pada siklus I diperoleh skor 30,5 dengan kategori baik, pada siklus II diperoleh skor 33,5 dengan kategori sangat baik dan pada siklus III meningkat dengan perolehan skor 35 dengan kategori sangat baik. Hasil belajar siswa dalam pembelajaran globalisasi menggunakan pendekatan inkuiri meningkat pada setiap siklusnya, dapat dilihat pada pra siklus nilai rata - rata siswa sebesar 58,97 dengan persentase ketuntasan klasikal 41,03\%, sedangkan pada siklus I nilai rata - rata naik menjadi 60,13 dengan persentase ketuntasan $43,09 \%$ dan pada siklus II nilai rata - rata naik menjadi 85,51 dengan persentase 94,87\%. Berdasarkan kesimpulan yang disampaikan maka hipotesis penelitian yaitu pendekatan inkuiri dapat meningkatkan hasil belajar pada siswa kelas IV SDN Pegajahan I Kota Cirebon dinyatakan diterima.

Saran yang dapat diberikan peneliti berdasarkan simpulan hasil penelitian sebagai berikut. Agar pembelajaran dapat berjalan dengan kondusif, maka guru dalam merencanakan dan melaksanakan pembelajaran harus memilih model/ pendekatan pembelajaran yang sesuai dengan karakteristik siswa, sehingga tujuan pembelajaran dapat tercapai. Di harapkan setiap guru dapat memanfaatkan segala media pembelajaran yang sesuai dengan materi pembelajaran sehingga siswa lebih tertarik dan lebih mudah memahami pelajaran. Guru dalam memberikan pertanyaan-pertanyaan sebaiknya menggunakan bahasa yang lebih mudah dipahami oleh siswa. Melalui pendekatan inkuiri, siswa diharapkan dapat menemukan, memecahkan persoalan dengan suatu proses percobaan untuk menemukan suatu jawaban sehingga siswa mengalami langsung dalam memperoleh ilmu pengetahuan.

\section{Daftar Pustaka}

Abimanyu, S. (2008). Strategi Pembeajaran. Jakarta: Dirjen Dikti.

Arikunto, S. (2013). Prosedur Penelitian Suatu Pendekatan Praktik. Jakarta: Rineka Cipta.

BSNP. (2006). Standar isi dan standar kompetensi lulusan untuk satuan

Caruban: Jurnal Ilmiah Pendidikan Dasar 3(1), 1-14, Januari 2020

DOI: http://dx.doi.org/10.33603/.v3i1.2897, p-ISSN 2615-1391, e-ISSN 2620-3219

CProdi PGSD Universitas Swadaya Gunung Jati 
pendidikan dasar SD/MI. Jakarta: BP. Cipta Jaya.

Djauhar, S. M. (2008). Pengembangan Bahan Pembelajaran SD. Jakarta:

Direktorat Jendral Pendidikan Tinggi Departemen Pendidikan Nasional.

Narbuko, C., \& Ahmadi, A. (2007). Metode Penelitian. Jakarta: Bumi Aksara.

Poerwanti, E. (2008). Assesmen Pembelajaran SD. Jakarta: Departemen Pendidikan Nasional.

Sudjana, N. (2008). Dasar-Dasar Proses Belajar Mengajar. Bandung: Sinar Baru Algesindo.

Wibawa, B., \& Mukti, F. (2011). Media Pengajaran. Bandung: CV Maulana. 